\title{
Images of the Prophet Muhammad in English Literature
}

\author{
Abdur Raheem Kidwai \\ New York: Peter Lang, 2018. 168 pages.
}

'Literary Orientalism', a significant and fast-emerging sub-genre, is simply defined as "the study of the (mis)representation of Islam and Muslims in the English (literary) works." In this field, one of the prominent Muslim writers from India is Abdur Raheem Kidwai (Professor of English, and Director, K.A. Nizami Centre for Quranic Studies, Aligarh Muslim University, India). Some of his previous works in this genre include Orientalism in Lord Byron's Turkish Tales (1995); The Crescent and the Cross (1997); Stranger than Fiction (2000); Literary Orientalism (2009); Believing and Belonging (2016); and Orientalism in English Literature (2016).

Consisting of a preface and three chapters, this book recounts and analyzes "the image of Prophet Muhammad, as reflected in English literary texts from the twelfth to nineteenth centuries." It "seeks to promote a better understanding between the Muslim world and the West against the backdrop of the Danish cartoons and the deplorable tragedy of $9 / 11$, which has evoked a general interest in things Islamic." Kidwai acknowledges that his book is a new addition to other works analysing portrayals of the Prophet's blessed life, including Byron Porter Smith's Islam in English Literature (1937), 'Adnān Muhammad al-Wazzān's Șūrat al-islām fì-l-adab al-inklīzī (2 vols., 1998), and Matthew Dimmock's Mythologies of the Prophet Muhammad in Early Modern English Culture (2013).

Kidwai deduces that "Peaceful coexistence is the only way forward for both the West and Muslims. For, in the first place it was mainly the lack of communication and authentic sources which had prompted such otherwise humane, sensitive creative writers as Dante, Shakespeare, Voltaire and others to include in their works vituperative, grotesque and, of course, absolutely baseless stories directed against the Prophet" (xii). In the charged contemporary context, what is "more reassuring and refreshing to note" is that "a host of Western scholars [are] identifying and highlighting new positives about Islam and the Prophet" (xii). It is within this broader perspective that one of his major objectives is "to realize...the goal of bridging gaps and facilitating a better cross-cultural understanding" (xii). 
Chapter One, “The Distorting Mirror," investigates some of the earliest and medieval-era sources that led to "the fabrication of their hate-inspired portrait of the Prophet". Some of the texts and writers cited are Chanson de geste, La Chanson de Roland, Dante's Divine Comedy, Peter the Venerable, Thomas Aquinas, Edward Gibbon, Voltaire, and Goethe. "Behind [their] wilful misrepresentation," the author opines, "were mainly the propagandist clergy, overzealous polemicists and some reckless travellers to Muslim lands." The common theme across their representations is "their unconcern for facts or history and their hatred for Islam," as they "did not or could not reconcile to the meteoric rise of a highly successful rival to the Christian theology and power." In the works of this era, "the Prophet [is] the object of their vilification and invectives" (xi). For example, Kidwai finds that Peter the Venerable was "the key figure in the production of polemical and fabricated material against Islam/the Prophet" (16); and while Aquinas "re-echoes Peter's view" (19), "Goethe (1749-1832) surpasses all Western writers in presenting a sympathetic, nay favourable estimate of the Prophet" (31). This chapter concludes with the observation that "English men of letters conceived and projected their image of the Prophet" against the backdrop of tropes already "tainted by the misconception, misperceptions and half-truths" in circulation. The Prophet's representation in most of these writings is "regrettably shot through with distortion of facts, invention of scurrilous reports, slanderous stories, and misinterpretation with the objective of disparaging him" (31).

Chapter Two, "The Crescent in the West," recounts representations of the Prophet in chronological order-ranging from such figures as William Langland, Geoffrey Chaucer, and, Christopher Marlowe to Samuel Coleridge, Thomas Moore, Lord Byron, and Thomas Carlyle—and "reflects the dominating influence" of the medieval legacy. The "understanding and depiction of the Prophet," by these writers, "is largely hostile, teeming with factual errors, opprobrious stereotypes, and even malicious fiction" because they were "fed" on the above-mentioned sources of which "hostility towards the Prophet is the hallmark" (32). This chapter, in a nutshell, surveys "the evolution of the Prophet's image, from an impostor to that of a hero in the annals of English literature" (112). For example, regarding Lydgate (the author of Fall of Princes), Kidwai is of the opinion that he presents an "outright negative, rather loathsome treatment of Islam and the Prophet"; "he presents the Prophet in the darkest colours. He hurls all sorts of false allegations with the only objective of discrediting, even demonizing 
him" (43). About Southey, he writes that "among the Romantic writers Southey has written most about Islam and Muslims", for he re-echoes the "medieval polemics in his opinion of the Prophet" (81-82); and about Byron he writes that his "allusions to Islam, the Prophet and Muslims", which appear mostly in his Turkish Tales, are "reflective of Byron's cross-cultural sympathies" (96). In stark contrast to most of these depictions, Carlyle's ground-breaking lecture of 1840, "The Hero as Prophet" (which forms a part of his On Heroes, Hero-Worship and the Heroic in History, 1927), is "essentially historical; it is like a milestone, a trend setter in that it helped the West perceive the Prophet's life and achievements in a clear light, free from the air of prejudice and half-truths" (105). He insists that Carlyle's lecture "helped many... appreciate the Prophet's sincerity of purpose, nobility of his mission and universality of his teachings" (107).

In the twentieth century, biographies or inter-cultural and historical studies by writers like William Montgomery Watt, Annemarie Schimmel, Karen Armstrong, John L. Esposito, and others "represent the new tolerant perspective which recognizes the Prophet's greatness and glory" (xii). Kidwai devotes Chapter Three to this positive trend, aptly entitled "Towards Fairness and Truth". This chapter begins with an interesting and insightful note: "Notwithstanding the highly regrettable and detestable portrayal of the Prophet down the centuries... which makes a sad, depressing reading, it is gratifying that since early twentieth century there has been some fairness in the West's treatment of the Prophet-in literary texts, academic publications particularly in the broad field of Islamic studies, and more importantly in a spate of historical and cultural studies, acknowledging the gross injustice and hostility in the West's representation" (120). These works, in Kidwai's assessment, have done "justice, to a large extent, to the Prophet's genius and his life-ennobling message" (120), and thus "reflect a sea-change in the representation of Prophet Muhammad (peace be upon him)" in twentieth/twenty-first century English literature.

Though most of the literary texts of earliest and medieval eras have portrayed the image of the Prophet in a ridiculous, damaging, and fabricated way, what becomes evident from the works of the last and present centuries is that "truth ultimately prevails" and "falsehood eventually" vanishes. Western writings of our time are almost unanimously seen "regretting and condemning the earlier hate-inspired portraits of the Prophet and instead celebrating the Prophet's illustrious contributions." Having surveyed the English literary and academic texts of last eight centuries, and having 
provided a critical, concise, and crisp assessment of (mis)representations of the image of the Prophet in these works-a survey of "the evolution of the Prophet's image, from an impostor to that of a hero in the annals of English literature"-Kidwai has fairly justified both the title as well as the subject of his book. In sum, Kidwai's Images of the Prophet Muhammad in English Literature is a must-read for everyone interested in Literary Orientalism, cross-cultural studies, Islamic Studies, and in understanding the (mis)representation of the Prophet in the English literature.

Tauseef Ahmad Parray Assistant Professor, Islamic Studies Higher Education Department, Jammu \& Kashmir, India 